\title{
Pertumbuhan Mata Tunas Okulasi Tanaman Karet (Hevea brasiliensis) Pada Berbagai Konsentrasi ZPT Atonik
}

\author{
Rossy Mirasari* \\ Program Studi Pengelolaan Perkebunan, Politeknik Pertanian Negeri Samarinda, Samarinda 75242 \\ Rossymalik678@gmail.com \\ *Corresponding author
}

\begin{abstract}
Abstrak - Penelitian ini bertujuan untuk mengetahui pengaruh pemberian Atonik dalam berbagai konsentrasi terhadap pertumbuhan mata tunas okulasi bibit karet pada stadium stum mata tidur. Bibit stum mata tidur merupakan bibit yang mata tunasnya belum tumbuh. Kelebihannya adalah ringan, mudah diangkut, dan biayanya murah. Namun persentase kematian bibit cukup besar dibandingkan dengan stadium lain. Karena itu perlu untuk diberi beberapa perlakuan untuk meningkatkan pertumbuhan mata tunas pada stum mata tidur tersebut. Salah satu hal yang dapat digunakan untuk membantu pertumbuhan mata tunas adalah dengan pemberian hormon atau zat pengatur tumbuh. Konsentrasi yang digunakan adalah Atonik 0,5 ml/liter air, Atonik 1 $\mathrm{ml} /$ liter air , Atonik 1,5 ml/liter air , dan tanpa penggunaan Atonik. Sedangkan perlakuan dasar diberikan sama terhadap semua bibit karet. Hasil penelitian menunjukkan bahwa konsentrasi Atonik 1,5 $\mathrm{ml} /$ liter air memberikan pengaruh paling baik dan berbeda nyata terhadap pertumbuhan mata tunas okulasi bibit karet pada semua parameter pengamatan, yaitu panjang tunas, jumlah daun dan diameter tunas, dibandingkan dengan perlakuan konsentrasi Atonik lainnya
\end{abstract}

Kata kunci - Bibit Karet, Okulasi, Stum Mata Tidur, Zat Pengatur Tumbuh, Atonik

\section{PENDAHULUAN}

Karet alam merupakan salah satu komoditi pertanian yang penting bagi Indonesia karena banyak menunjang perekonomian negara. Hasil devisa yang diperoleh dari karet cukup besar. Bahkan Indonesia pernah menguasai produksi karet dunia (Anonim, 2009).

Berdasarkan data Direktorat Jenderal Perkebunan (2017), karet merupakan sumber devisa negara terbesar kedua di bidang perkebunan setelah sawit. Luas areal perkebunan karet di Indonesia pada tahun 2017 adalah 3.672.123 ha.

Walaupun saat ini karet alam memiliki jumlah produksi dan konsumsinya jauh di bawah karet sintetis atau karet buatan pabrik, tetapi sesungguhnya karet alam belum tergantikan oleh karet sintetis. Karet alam memiliki kelebihan-kelebihan dibandingkan karet sintetis
Banyak perkebunan-perkebunan karet yang tersebar di berbagai propinsi di Indonesia. Perkebunan karet yang besar banyak diusahakan oleh pemerintah serta swasta. Sedangkan perkebunan-perkebunan karet dalam skala kecil pada umumnya dimiliki oleh rakyat. Namun kondisi perkaretan di Indonesia terutama karet rakyat sampai saat ini belum menunjukkan hasil yang menggembirakan. Produktivitas karet rakyat masih jauh lebih rendah bila dibandingkan produktivitas karet dari perusahaan besar swasta maupun milik negara.

Budidaya karet bertujuan untuk menghasilkan getah cair (lateks) yang berkualitas baik dan produksi yang tinggi (ton/ha). Perwujudan usaha tani yang berhasil hanya dapat dicapai secara optimal jika cara budidaya dilakukan secara intensif dengan memadukan berbagai unsur yang dapat meningkatkan produksi. Unsur-unsur yang mempengaruhi produksi karet adalah keadaan lingkungan tempat tumbuh tanaman, klon tanaman, dan teknik budidaya.

Guna menunjang produksi karet yang optimum, banyak faktor yang harus diperhatikan dalam budidaya karet, diantaranya adalah penyediaan bibit karet yang baik. Bibit karet sebaiknya berasal dari klon-klon unggul, contohnya klon PB 260 yang termasuk klon yang direkomendasikan untuk pertanaman komersial. Dalam pelaksanaan program peremajaan ataupun penanaman areal baru dianjurkan menggunakan bibit okulasi, sebab dapat menghasilkan tanaman karet yang berproduksi lebih baik dibandingkan dengan bibit generatif. Bibit okulasi merupakan satu-satunya cara pengembangan tanaman secara vegetatif pada tanaman karet.

Menurut Setiawan dan Andoko (2009), untuk mendapatkan bibit yang baik, tanaman karet dianjurkan untuk menggunakan klon-klon unggul dengan menggunakan teknik okulasi. Okulasi merupakan penempelan mata tunas dari tanaman batang atas ke tanaman batang bawah yang keduanya bersifat unggul. Dengan cara ini akan terjadi penggabungan sifat-sifat baik dari dua tanaman dalam waktu yang relatif pendek dan memperlihatkan pertumbuhan yang seragam. Tujuan utama membuat bibit okulasi adalah agar produksi bisa lebih tinggi.

Jenis bibit asal pembiakan okulasi yang selama ini dipakai memiliki beberapa bentuk stadium. Setiap bentuk memiliki kebaikan dan kekurangan masingmasing. Salah satu macam bibit klonal tersebut adalah stum mata tidur. 
Bibit stum mata tidur merupakan bibit yang mata tunasnya belum tumbuh. Bibit stum mata tidur diperoleh dari bibit okulasi yang tumbuh di pembibitan selama kurang dari 2 bulan setelah pemotongan. Kelebihannya adalah ringan, mudah diangkut, dan biayanya murah. Namun persentase kematian bibit cukup besar dibandingkan dengan stadium lain (Anonim, 2009). Tingginya penyebab kematian tersebut karena kurangnya hormon untuk mendorong proses morfogenesis kalus untuk membentuk akar dan tunas, dan kurangnya kestabilan genetic. Karena itu perlu untuk diberi beberapa perlakuan untuk meningkatkan pertumbuhan mata tunas pada stum mata tidur tersebut.

Salah satu hal yang dapat digunakan untuk membantu pertumbuhan mata tunas adalah dengan pemberian hormon atau zat pengatur tumbuh (ZPT). ZPT dapat diberikan pada perakaran maupun langsung pada mata tunas.

Zat Pengatur Tumbuh (ZPT) adalah molekul-molekul yang kegiatannya mengatur reaksi-reaksi metabolik penting. Molekul-molekul tersebut dibentuk didalam organisme dengan proses metabolik dan tidak berfungsi dalam nutrisi. Istilah ZPT mencakup hormon tumbuhan (alami) dan senyawa-senyawa buatan yang dapat mengubah tumbuh dan perkembangan tanaman. Nama senyawa tersebut dapat pula menyatakan kegiatan fisiologisnya, misalnya zat tumbuh daun, zat tumbuh akar dan sebagainya (Abidin, 2010).

ZPT dan hormon dibutuhkan dalam jumlah sedikit, dapat merangsang, menghambat, maupun mengubah berbagai proses fisiologi tanaman (Heddy, 2009). ZPT dengan berbagai kegunaan ini sudah banyak dijumpai di pasaran.

Salah satu ZPT yang dapat digunakan adalah Atonik. Atonik adalah zat perangsang tumbuh berbentuk cairan, berwarna coklat dan merupakan senyawa kimia yang berfungsi sebagai perangsang tumbuhan. Atonik memiliki kandungan unsur hara yang diperlukan oleh tanaman diantaranya $\mathrm{S}, \mathrm{Bo}, \mathrm{Fe}, \mathrm{Mn}, \mathrm{Mg}, \mathrm{Zn}, \mathrm{Cu}, \mathrm{Mo}$ dan $\mathrm{Ca}$ dalam jumlah relatif sedikit, yang merupakan persenyawaan kimia yang bahan aktif Nitro aromatic. Bahan aktif Atonik adalah Natrium orto nitrofenol, Natrium para nitrofenol, Natrium 2,4 dinitrofenol dan Natrium-5 nitrogualakol (Kusumo, 2010).

Atonik bukan fitohormon atau pestisida tetapi sebagai zat kimia yang dapat merangsang proses biokimia dan fisiologis cadangan makanan pada tanaman. Atonik adalah suatu zat pengatur tumbuh tanaman, tetapi atonik tidak sama dengan hormon. Hormon hanya dapat merangsang bagian tumbuhan secara terbatas sedangkan atonik dapat merangsang seluruh jaringan tumbuhan secara biokimia dan langsung meresap melalui akar, batang dan daun sehingga mempercepat pertumbuhan tanaman (Abidin, 2010).

Zat pengatur tumbuh dapat mendorong pertumbuhan akar sehingga penyerapan hara menjadi lebih efektif. ZPT Atonik di dalam tanaman dapat berfungsi mendorong pertumbuhan tanaman, memiliki daya panen, memperbaiki mutu dan meningkatkan hasil tanaman. Dalam cara kerjanya, Atonik cepat terserap oleh tanaman dan merangsang protoplasmatik sel serta mempercepat perkecambahan dan perakaran, tetapi bila konsentrasinya berlebihan maka dapat menghambat pertumbuhan. Bila Atonik konsentrasinya optimum, maka proses sintesis protein dapat meningkat. Protein yang berbentuk dipergunakan sebagai bahan penyusun tanaman (Lestari, 2011).

Penggunaan ZPT Atonik pada konsentrasi yang tepat diharapkan dapat meningkatkan pertumbuhan. Penelitian ini bertujuan untuk mengetahui pengaruh pemberian Atonik dalam berbagai konsentrasi terhadap pertumbuhan mata tunas bibit karet stum mata tidur.

Hasil penelitian ini diharapkan dapat memberikan informasi bagi para petani, pengembang bibit, atau siapa pun yang berminat pada pembibitan tanaman karet mengenai penggunaan ZPT Atonik dengan konsentrasi yang tepat dapat meningkatkan pertumbuhan mata tunas bibit karet stum mata tidur.

\section{METODOLOGI}

\section{Tempat dan Waktu Penelitian}

Penelitian ini dilaksanakan sekitar 4 (empat) bulan, sejak Juli hingga Oktober 2014. Kegiatannya meliputi persiapan, pelaksanaan, pengumpulan data, pengolahan data dan penulisan laporan. Lokasi penelitian dilaksanakan di Persemaian Politeknik Pertanian Negeri Samarinda

\section{Alat dan Bahan}

Alat-alat yang digunakan dalam penelitian adalah alat tulis, ember, gelas ukur, gembor, sprayer, cangkul, parang, tugal, timbangan, meteran, mikrokalifer dan kamera.

Bahan-bahan yang digunakan adalah top soil, polybag, pupuk TSP, pupuk NPK mutiara, bibit karet stum mata tidur klon PB 260, ZPT Rootone F, Atonik, dan air.

\section{Metode Penelitian}

Dalam penelitian ini digunakan pengumpulan data primer dan sekunder dengan cara sebagai berikut :

a. Data primer berupa penelitian di lapangan.

Penelitian ini di susun dalam Rancangan Acak Kelompok (RAK) yang terdiri atas 1 faktor dengan jumlah ulangan sebanyak 12 ulangan. Perlakuan pemberian Atonik terdiri dari 4 taraf yaitu: $\mathrm{A} 0=$ tanpa pemberian atonik, $\mathrm{A} 1=0,5 \mathrm{ml} / \mathrm{liter}$ air, $\mathrm{A} 2=1 \mathrm{ml} / \mathrm{liter}$ air, dan $\mathrm{A} 3=1,5 \mathrm{ml} / \mathrm{liter}$ air.

Untuk melihat respon tanaman terhadap perlakuan tersebut dilakukan analisis ragam. Jika hasil analisis ragam menunjukkan pengaruh yang nyata dari perlakuan yang diberikan maka analisis dilanjutkan dengan Uji Beda Nyata Terkecil (BNT) pada taraf 5 persen. Melalui uji BNT dapat diketahui perbedaan pengaruh antara masing-masing taraf dari faktor perlakuan.

b. Data Sekunder 
Penelitian kepustakaan yaitu penelitian yang dilakukan dengan cara membaca dan mempelajari literatur-literatur yang berkaitan dengan masalah yang sedang diteliti.

\section{Prosedur Penelitian}

Prosedur penelitian adalah sebagai berikut :

a. Persiapan

Sebelum pelaksanaan penelitian, terlebih dahulu melakukan persiapan alat dan bahan yang akan dipergunakan serta menyiapkan lokasi tempat bibit karet. Masing-masing polybag diisi dengan top soil dan pupuk TSP sebagai pupuk dasar.

b. Pelaksanaan

Sehari sebelum penanaman dilakukan penyiraman pada tiap polybag agar tanah menjadi lebih gembur dan tidak kering, sehingga lebih mudah dilakukan penugalan. Bibit karet dipilih dengan melihat hasil okulasi yang berwarna hijau dan berakar tunggal. Sebelum bibit karet ditanam ke dalam polybag, bibit terlebih dulu direndam dalam larutan Rootone F 2 gr/liter air selama 5 menit. Tiap polybag ditugal sedalam $30 \mathrm{~cm}$, lalu ditanami dengan bibit karet yang sudah diberi perendaman Rootone F. Satu jam sesudah penanaman, kembali dilakukan penyiraman. Penyemprotan Atonik mulai dilakukan seminggu setelah penanaman bibit ke polybag. Selanjutnya penyemprotan dilakukan setiap 2 minggu sekali.

c. Pemeliharaan

Penyiraman dilakukan 2 kali sehari yaitu pagi dan sore hari, atau tergantung dengan kondisi tanah. Pemupukan NPK mutiara dilakukan sebulan sekali sejak penanaman. Pengendalian gulma dan pemotongan tunas-tunas liar pada bibit karet dilakukan setiap minggu.

d. Pengamatan

Parameter yang diamati meliputi : panjang tunas (cm), jumlah daun (helai) dan diameter tunas $(\mathrm{cm})$. Pengamatan dilakukan setiap 2 minggu sekali, sampai 3 kali pengamatan. Pengukuran panjang tunas menggunakan meteran, dari pangkal tunas hingga ujung tunas. Diameter tunas diukur dengan mikrokalifer.

\section{HASIL DAN PEMBAHASAN}

\section{A. Hasil}

\section{Panjang Tunas (cm)}

1). Umur 2 minggu setelah tanam (2 MST)

Berdasarkan sidik ragam pengaruh pemberian Atonik pada berbagai konsentrasi terhadap rata-rata panjang tunas bibit karet stum mata tidur umur 2 minggu setelah tanam menunjukkan beda sangat nyata. Hasil tertinggi diperoleh pada perlakuan pemberian Atonik 1,5 ml/liter air (A3) yaitu rata-rata $0,79 \mathrm{~cm}$ (tabel 1).
Tabel 1. Hasil pengamatan pengaruh berbagai konsentrasi Atonik terhadap rata - rata panjang tunas bibit karet

\begin{tabular}{|c|c|c|c|c|}
\hline No. & Perlakuan & \multicolumn{3}{|c|}{ Panjang Tunas (cm) } \\
\cline { 3 - 5 } & & $\begin{array}{c}2 \\
\text { MST }\end{array}$ & 4 MST & 6 MST \\
\hline 1. & A0 & $0,56^{\mathrm{d}}$ & $11,64^{\mathrm{d}}$ & $16,28^{\mathrm{d}}$ \\
\hline 2. & A1 & $0,63^{\mathrm{c}}$ & $12,54^{\mathrm{c}}$ & $18,75^{\mathrm{c}}$ \\
\hline 3. & A2 & $0,68^{\mathrm{b}}$ & $14,22^{\mathrm{b}}$ & $22,50^{\mathrm{b}}$ \\
\hline 4. & A3 & $0,79^{\mathrm{a}}$ & $15,25^{\mathrm{a}}$ & $25,83^{\mathrm{a}}$ \\
\hline
\end{tabular}

Keterangan : Angka rata-rata yang diikuti oleh huruf yang beda menunjukkan beda nyata pada uji BNT 5\%

2). Umur 4 minggu setelah tanam (4 MST)

Berdasarkan sidik ragam pengaruh pemberian Atonik pada berbagai konsentrasi terhadap ratarata panjang tunas bibit karet stum mata tidur umur 4 minggu setelah tanam menunjukkan hasil beda sangat nyata. Hasil tertinggi diperoleh pada perlakuan pemberian Atonik 1,5 ml/liter air (A3) yaitu rata-rata $15,25 \mathrm{~cm}$ (tabel 1).

3). Umur 6 minggu setelah pindah tanam (6 MST)

Berdasarkan sidik ragam pengaruh pemberian Atonik pada berbagai konsentrasi terhadap ratarata panjang tunas bibit karet stum mata tidur umur 6 minggu setelah tanam menunjukkan hasil beda sangat nyata. Hasil tertinggi diperoleh pada perlakuan pemberian Atonik 1,5 $\mathrm{ml} /$ liter air (A3) yaitu rata-rata 25,83 $\mathrm{cm}$ (tabel 1).

Hal ini menunjukkan bahwa pemberian Atonik pada konsentrasi 1,5 ml/liter air merupakan konsentrasi yang tepat dibandingkan konsentrasi lainnya, dan dapat aktif merangsang pertumbuhan tunas bibit karet stum mata tidur. Pengaruh nyata pemberian Atonik terhadap Panjang tunas bibit karet stum mata tidur sudah dapat dilihat sejak bibit berumur 2 minggu setelah tanam, dan hal ini berlanjut hingga 4 dan 6 minggu setelah tanam.

\section{Jumlah Daun (helai)}

1). Umur 4 minggu setelah tanam (4 MST)

Berdasarkan sidik ragam pengaruh pemberian Atonik pada berbagai konsentrasi terhadap ratarata jumlah daun bibit karet stum mata tidur umur 4 minggu setelah tanam menunjukkan hasil beda sangat nyata. Hasil tertinggi diperoleh pada perlakuan pemberian Atonik 1,5 ml/liter air (A3) yaitu rata-rata 2,75 helai (tabel 2).

Tabel 2. Hasil pengamatan pengaruh berbagai konsentrasi Atonik terhadap rata - rata jumlah daun bibit karet

\begin{tabular}{|c|c|c|c|c|}
\hline \multirow{2}{*}{ No. } & Perlakuan & \multicolumn{3}{|c|}{ Jumlah daun (helai) } \\
\cline { 3 - 5 } & & 2 MST & 4 MST & 6 MST \\
\hline 1. & A0 & 0 & $1,58^{\mathrm{c}}$ & $4,25^{\mathrm{d}}$ \\
\hline 2. & A1 & 0 & $1,92^{\mathrm{c}}$ & $5,17^{\mathrm{c}}$ \\
\hline 3. & A2 & 0 & $2,33^{\mathrm{b}}$ & $5,92^{\mathrm{b}}$ \\
\hline
\end{tabular}




\begin{tabular}{c|c|c|c|c|}
\hline 4. & $\mathrm{~A} 3$ & 0 & $2,75^{\mathrm{a}}$ & $7,17^{\mathrm{a}}$ \\
\hline Keterangan : & Angka rata-rata yang diikuti oleh \\
& huruf yang beda menunjukkan \\
& beda nyata pada uji BNT 5\%
\end{tabular}

3). Umur 6 minggu setelah pindah tanam (6 MST)

Berdasarkan sidik ragam pengaruh pemberian Atonik pada berbagai konsentrasi terhadap ratarata jumlah daun bibit karet stum mata tidur umur 6 minggu setelah tanam menunjukkan hasil beda sangat nyata. Hasil tertinggi diperoleh pada perlakuan pemberian Atonik 1,5 $\mathrm{ml} /$ liter air (A3) yaitu rata-rata 7,17 helai (tabel 2) .

Hasil terbaik juga diperoleh pada perlakuan pemberian Atonik 1,5 ml/liter air terhadap pertumbuhan jumlah daun bibit karet. Hal ini terlihat sejak usia bibit 4 minggu setelah tanam.

\section{Diameter Tunas (cm)}

1). Umur 2 minggu setelah tanam (2 MST)

Berdasarkan sidik ragam pengaruh pemberian Atonik pada berbagai konsentrasi terhadap ratarata diameter tunas bibit karet stum mata tidur umur 2 minggu setelah tanam menunjukkan beda sangat nyata. Hasil tertinggi diperoleh pada perlakuan pemberian Atonik $1,5 \mathrm{ml} / \mathrm{liter}$ air (A3) yaitu rata-rata $0,30 \mathrm{~cm}$ (tabel 3$)$.

Tabel 3. Hasil pengamatan pengaruh berbagai konsentrasi Atonik terhadap rata rata diameter tunas bibit karet

\begin{tabular}{|c|c|c|c|c|}
\hline No. & Perlakuan & \multicolumn{3}{|c|}{ Diameter Tunas (cm) } \\
\cline { 3 - 5 } & & $\begin{array}{c}2 \\
\text { MST }\end{array}$ & 4 MST & $\begin{array}{c}6 \\
\text { MST }\end{array}$ \\
\hline 1. & A0 & $0,15^{\mathrm{c}}$ & $0,40^{\mathrm{d}}$ & $0,60^{\mathrm{d}}$ \\
\hline 2. & A1 & $0,22^{\mathrm{b}}$ & $0,53^{\mathrm{c}}$ & $0,73^{\mathrm{c}}$ \\
\hline 3. & A2 & $0,25^{\mathrm{b}}$ & $0,64^{\mathrm{b}}$ & $0,83^{\mathrm{b}}$ \\
\hline 4. & A3 & $0,30^{\mathrm{a}}$ & $0,73^{\mathrm{a}}$ & $0,94^{\mathrm{a}}$ \\
\hline
\end{tabular}

Keterangan : Angka rata-rata yang diikuti oleh huruf yang beda menunjukkan beda nyata pada uji BNT 5\%

2). Umur 4 minggu setelah tanam (4 MST)

Berdasarkan sidik ragam pengaruh pemberian Atonik pada berbagai konsentrasi terhadap ratarata diameter tunas bibit karet stum mata tidur umur 4 minggu setelah tanam menunjukkan hasil beda sangat nyata. Hasil tertinggi diperoleh pada perlakuan pemberian Atonik 1,5 ml/liter air (A3) yaitu rata-rata $0,73 \mathrm{~cm}$ (tabel 3).

3). Umur 6 minggu setelah pindah tanam (6 MST)

Berdasarkan sidik ragam pengaruh pemberian Atonik pada berbagai konsentrasi terhadap ratarata diameter tunas bibit karet stum mata tidur umur 6 minggu setelah tanam menunjukkan hasil beda sangat nyata. Hasil tertinggi diperoleh pada perlakuan pemberian Atonik 1,5 $\mathrm{ml} /$ liter air (A3) yaitu rata-rata 0,94 cm (tabel 3)

Pertumbuhan diameter tunas juga diperoleh hasil terbaik pada konsentrasi 1,5 ml Atonik. Pemberian Atonik sudah memberikan pengaruhnya sejak 2 minggu setelah bibit karet ditanam hingga tiap 2 minggu pengamatan selanjutnya.

\section{B. Pembahasan}

Pertumbuhan dan perkembangan suatu tanaman ditandai antara lain dengan pertambahan ukuran tanaman. Berdasarkan hasil dapat diketahui bahwa penggunaan ZPT Atonik pada berbagai konsentrasi memiliki pengaruh terhadap pertumbuhan mata tunas okulasi bibit karet stum mata tidur. Hal ini dapat dilihat dari hasil pengamatan dan hasil analisis sidik ragam terhadap semua parameter, yaitu panjang tunas, jumlah daun, dan diameter tunas bibit karet.

Hasil penelitian ini menunjukkan bahwa peningkatan konsentrasi Atonik memberikan pengaruh yang berbeda nyata. Makin tinggi konsentrasi Atonik yang diberikan maka semakin baik pula pertumbuhan panjang dan diameter tunas, serta jumlah daun. Meskipun belum diketahui batas optimum pemberian konsentrasi Atonik tersebut.

Hal ini diduga karena adanya kandungan auksin pada Atonik, sehingga penambahan auksin secara eksogen akan meningkatkan kemampuan tanaman untuk tumbuh. Kandungan auksin pada Atonik akan meningkatkan aktivitas auksin endogen pada tanaman sehingga proses pembelahan sel dan pembentukan organ tanaman akan lebih cepat.

Selain itu pada Atonik mengandung senyawa dinitrofenol yang berfungsi sebagai pemecah dormansi tunas, mengaktifkan penyerapan hara dan memacu keluarnya kuncup. Senyawa nitro aromatik juga terdapat pada Atonik, yang berfungsi untuk memacu pertumbuhan tunas (Pakpahan, 2018). Maka dengan pemberian Atonik diduga dapat meningkatkan aktivitas nitrofenol dalam mempengaruhi konsentrasi IAA dalam tanaman. Atonik yang diserap oleh tanaman akan mempercepat aliran protoplasmik dan mengaktifkan metabolisme. Pemberian Atonik juga diduga dapat meningkatkan permeabilitas dinding sel yang akan meningkatkan penyerapan unsur hara pembentuk klorofil yang sangat diperlukan untuk mempertinggi fotosintesis.

Semakin tinggi konsentrasi Atonik ternyata menunjukkan adanya peningkatan pertumbuhan mata tunas. Hasil ini dapat dilihat pada semua parameter dan pada tiap pengamatan, meskipun tidak seluruhnya berbeda nyata. Pada parameter jumlah daun di 4 MST (Minggu Setelah Tanam) antara A0 (tanpa Atonik) dan A1 (Atonik 0,5 ml/liter air) menunjukkan perbedaan yang tidak nyata. Demikian juga halnya pada parameter diameter tunas di 2 MST antara A1 dan A2 (Atonik 1 $\mathrm{ml} /$ liter air) yang menunjukkan perbedaan tidak nyata.

Secara keseluruhan perlakuan A3 (Atonik 1,5 ml/liter air) memberikan hasil terbaik dan berbeda nyata 
dibandingkan perlakuan lainnya, baik pada semua parameter maupun pada tiap pengamatan. Sedangkan A0 memberikan hasil terendah pada semua parameter dan pada tiap pengamatan. Hal ini menunjukkan bahwa pemberian Atonik secara umum mampu merangsang pertumbuhan tanaman, khususnya pertumbuhan mata tunas okulasi bibit karet stum mata tidur. Penambahan zat-zat yang berasal dari Atonik, meskipun dalam jumlah yang kecil tetapi sangat dibutuhkan oleh tanaman dapat membantu mengaktifkan kerja enzim.

Atonik yang diberikan pada tanaman menimbulkan berbagai macam efek bagi pertumbuhan tanaman, dalam hal ini terhadap panjang dan diameter tunas, serta jumlah daun. ZPT yang diberikan pada tanaman dengan jumlah tertentu terbukti dapat mendukung pertumbuhan tanaman.

Pengaruh pemberian Atonik juga terlihat pada hasil penelitian Pakpahan (2018) terhadap pertumbuhan sirih merah. Dari hasil penelitian tersebut didapatkan hasil bahwa terjadi peningkatan persentase tanaman tumbuh, persentase tanaman bertunas, jumlah daun, panjang tanamann dan panjang akar primer.

Setiap ZPT yang diberikan pada tanaman memiliki potensi untuk meningkatkan pertumbuhan, serta sering bekerja secara tandem satu sama lain (Gana, 2010). Sesuai dengan pendapat Sitinjak (2015) yang menyatakan bahwa hormon dapat bekerja secara efektif pada jumlah tertentu. Atonik diperlukan dengan konsentrasi tertentu untuk bekerjasama dengan hormon lain dalam mempengaruhi ekspresi gen pada tingkat transkripsi, pembelahan sel dan pertumbuhan. Atonik dapat merangsang seluruh jaringan tumbuhan secara biokimia dan langsung meresap melalui akar, batang dan daun sehingga mempercepat pertumbuhan tanaman.

Menurut Harjadi (2009), fase vegetatif terutama terjadi pada fase perkembangan akar, daun dan batang baru. Fase ini berhubungan dengan 3 proses penting yaitu pembelahan sel, perpanjangan sel dan tahap pertama dari diferensiasi sel. Dengan pendapat-pendapat tersebut dapat disimpulkan bahwa dengan pemberian atonik maka dapat memicu terjadinya proses-proses pembelahan, perpanjangan, dan diferensiasi sel mata tunas okulasi bibit karet yang lebih cepat dibandingkan tanpa atonik.

Hasil pengamatan juga menunjukkan bahwa tanpa pemberian atonik ternyata masih dapat menumbuhkan mata tunas okulasi bibit karet meskipun hasilnya lebih rendah. Hal ini antara lain karena keberhasilan okulasi itu sendiri, dan adanya pemberian pupuk pada media tanam, serta pemberian ZPT Rootone F pada akar bibit karet sebelum ditanam ke polybag. Dengan demikian peneliti tetap mengharapkan pertumbuhan mata tunas okulasi bibit karet, meskipun tanpa atonik. Peneliti hanya ingin mengamati sejauh mana pemberian atonik pada berbagai konsentrasi dapat memberikan pengaruhnya terhadap pertumbuhan mata tunas okulasi.

\section{KESIMPULAN}

Pemberian ZPT atonik dapat memberikan pengaruh lebih baik dibandingkan tanpa atonik terhadap pertumbuhan mata tunas okulasi bibit karet stum mata tidur pada semua parameter pengamatan, yaitu panjang tunas, jumlah daun, dan diameter tunas. Semakin tinggi konsentrasi perlakuan atonik maka semakin baik pertumbuhan mata tunas okulasi bibit karet. Perlakuan A3 (Atonik 1,5 ml/liter air) memberikan hasil terbaik dan berbeda nyata dibandingkan perlakuan lainnya, baik berbeda konsentrasi maupun tanpa atonik, terhadap pertumbuhan mata tunas okulasi bibit karet, pada semua parameter dan pada tiap pengamatan.

Batasan maksimum konsentrasi ZPT Atonik dan pengaruhnya terhadap pertumbuhan mata tunas okulasi. Pengaruh frekuensi pemberian ZPT Atonik terhadap pertumbuhan mata tunas okulasi

\section{DAFTAR PUSTAKA}

Abidin, Z., 2010. Dasar-Dasar Pengetahuan Tentang Zat Pengatur Tumbuh. Angkasa, Bandung.

Anonim, 2009. Karet. Penebar Swadaya, Jakarta

Anonim, 2009. Zat Pengatur Tumbuh Atonik. Trubus, Jakarta.

Cahyono, B., 2010. Cara Sukses Berkebun Karet. Pustaka Mina, Jakarta

Direktorat Jenderal Perkebunan, 2017. Buku Statistik $\begin{array}{llll}\text { Karet } & \text { (Rubber) } 2017 \quad \text { - } & 2019 .\end{array}$ https://www.ditjenbun.pertanian.go.id

Gana, A. S.,2010. The Role of Synthetic Growth Hormones in Crop Multiplication and Improvement. African Journal of Biotechnology. $10 \quad(51) \quad: \quad 10330 \quad$ - 10334. https://www.academicjournals.org

Harjadi. S.S, 2009. Zat Pengatur Tumbuh. PT. Gramedia Pustaka Utama. Jakarta

Heddy, S., 2009. Hormon Tumbuh. CV. Rajawali, Jakarta

Irawan, A., 2008. Berbagai Cara Mengembangbiakkan Aneka Jenis Tanaman. Karya Remaja, Bandung

Kusumo, S. 2010. Zat Pengatur Tumbuh Tanaman. Yasaguna. Bandung

Lestari, B.L., 2011. Kajian ZPT Atonik dalam Berbagai Konsentrasi dan Interval Penyemprotan terhadap Produktivitas Tanaman Bawang Merah (Allium ascolanicum L.). Jurnal Rekayasa. 4 (1)

Pakpahan, F.E., 2018. Pengaruh Berbagai Konsentrasi ZPT Atonik Pada Pertumbuhan Berbagai Asal Batang Stek Sirih Merah (Piper crocatum Ruiz and Pav.). Jurnal Produksi Tanaman. 6 (6): 10801086.

Setiawan, D. H. dan Andoko, A., 2009. Petunjuk Lengkap Budidaya Karet. AgroMedia Pustaka, Jakarta.

Sitinjak, R. R., 2015. Pengaruh Atonik terhadap Stek Pucuk Tumbuhan Kakao (Theobroma cacao L). Jurnal Pro Life 2(1):19-25. https://www.akademik.uhn.ac.id 